\title{
Mean Tropospheric Residence Time of Cosmic-Ray-Produced Beryllium 7 at North Temperate Latitudes
}

\author{
J. F. BLEICHROdT \\ Medical Biological Laboratory TNO, Rijswijk Z. H., Netherlands
}

\begin{abstract}
By means of published data on the concentration of ${ }^{7} \mathrm{Be}$ in the troposphere between $30^{\circ}$ and $75^{\circ} \mathrm{N}$, together with concentrations measured over the Netherlands, the tropospheric content of ${ }^{7} \mathrm{Be}$ has been estimated. Comparison of this value with published rates of deposition of ${ }^{7} \mathrm{Be}$ in the same latitude band shows that the mean tropospheric residence time of this nuclide is probably not less than 22 days and is more likely of the order of 35 days. This is in agreement with previous estimates and not in agreement with the value of 1 week or less proposed recently by Martell and Moore.
\end{abstract}

\section{INTRODUCTION}

In a discussion of published estimates of the tropospheric residence time of aerosols carrying natural and artificial radioactive nuclides, Martell and Moore [1974] concluded that the mean tropospheric residence time of these aerosols is less than 1 week. Longer residence times, including those proposed for cosmic ray spallation products, were assumed to be in error.

The mean tropospheric residence time $\tau$ of cosmic-ray-produced nuclides can be deduced from measurements of the average tropospheric content $N$ (atoms $\mathrm{m}^{-2}$ ) and the mean deposition rate $D$ (atoms $\left.\mathrm{m}^{-2} \mathrm{~s}^{-1}\right)$ on the earth's surface $(\tau D=$ $N)$. It may also be calculated from the known tropospheric production rate $P$ and the measured deposition rate $(P=D(1$ $+\lambda \tau)$, where $\lambda$ is the disintegration constant of the nuclide) or from the ratio of the tropospheric concentrations of two nuclides with different half-lives, the residence times for the two being assumed to be identical.

At higher latitudes the last two procedures are not applicable because exchange of air between stratosphere and troposphere, which may influence the result appreciably, is not taken into account. Influx of stratospheric ${ }^{7} \mathrm{Be}$ down to an altitude of $3 \mathrm{~km}$ has been shown to occur by $R$. Reiter et al. [1971]. Assuming a mean tropospheric residence time of 30 days, Bleichrodt and van Abkoude [1963b] estimated that some $30 \%$ of the deposition of ${ }^{7} \mathrm{Be}$ at $50^{\circ} \mathrm{N}$ originates from the stratosphere; for a residence time of 7 days this percentage would be about 40. Walton and Fried [1962] showed that the highest value for the radioactivity ratio of ${ }^{7} \mathrm{Be}$ and ${ }^{32} \mathrm{P}$ observed in 14 rains at Westwood $\left(41^{\circ} \mathrm{N}, 74^{\circ} \mathrm{W}\right)$ might, for instance, result from exclusive irradiation of an air parcel within the troposphere for 68 days or from the presence of $12 \%$ of stratospheric air in a tropospheric air sample which was cleansed by rain 10 days before. A small percentage of stratospheric air might thus have a great influence on the residence time as estimated from nuclide ratios.

The first method of calculation mentioned above remains applicable if the stratosphere contributes significantly to the tropospheric inventory, because it is based on the definition of residence time, i.e., $\tau D=N$. It therefore seemed worthwhile to reestimate the mean tropospheric residence time of a cosmogenic nuclide by using this method and to compare the result with the value suggested by Martell and Moore [1974].

Tropospheric Content of ${ }^{7} \mathrm{BE}$

The amount of ${ }^{7} \mathrm{Be}$ in a column of air extending from the earth's surface to the tropopause can be computed when the

Copyright (c) 1978 by the American Geophysical Union. Paper number $8 \mathrm{C} 0029$

$0148-0227 / 78 / 068 C-0029 \$ 01.00$ concentration of ${ }^{7} \mathrm{Be}$ in air is known as a function of altitude. To construct a vertical concentration profile, as many data as possible have been collected (including those in Table 1) and plotted in Figure 1. Data for the same altitude and groups of data covering small altitude ranges were averaged. The average concentration of ${ }^{7} \mathrm{Be}$ in air at sea level was taken from Figure 2.

The question may be asked whether the average ${ }^{7} \mathrm{Be}$ concentration measured over land (Figure 2) equals that over the sea. On the average, the concentration of ${ }^{80} \mathrm{Sr}$ from nuclear tests was found not to differ significantly in surface air over land and ocean between $35^{\circ} \mathrm{N}$ and $55^{\circ} \mathrm{N}$ during the years 1966 1967 [Freudenthal, 1969]. Since the ${ }^{80} \mathrm{Sr}$ originated mainly from the stratosphere, from which injection into the troposphere depends on latitude, whereas a large part of the ${ }^{7} \mathrm{Be}$ in surface air has been produced in the troposphere with little horizontal variation in production rate [Lal and Suess, 1968], any difference in the concentrations over land and sea is probably smaller for ${ }^{7} \mathrm{Be}$ than for ${ }^{80} \mathrm{Sr}$.

The average values in Figure 1 show so much scatter that it may be doubted whether drawing an average concentration profile will lead to a realistic estimate of the tropospheric content of ${ }^{7} \mathrm{Be}$. To determine a minimum value for the tropospheric content and thus a minimum for the residence time, profile I in Figure I was drawn after rejection of the highest value of each group of data of which the average had been plotted. Curves II and III will certainly yield much closer approximations of the true tropospheric content.

By means of the curves in Figure 1 and data on the 1962 COESA (U.S. Committee on Extension to the Standard Atmosphere) standard atmosphere [Sissenwine, 1969] the amount of ${ }^{7} \mathrm{Be}$ in a column of air in the troposphere has been calculated by plotting the concentration against altitude in kilograms per square meter of pressure and integrating graphically between ground level and various tropopause heights. The results are shown in Table 2.

The number of ${ }^{7} \mathrm{Be}$ data obtained by aircraft did not allow an estimation of concentration profiles for different seasons. To minimize the influence of seasonal variations in the concentration of ${ }^{7} \mathrm{Be}$ in surface air and in the deposition of ${ }^{7} \mathrm{Be}$ ( discussion below), data have been averaged as much as pos- 1 sible for periods of a whole number of years.

\section{Average Deposition}

Published values of the total deposition of ${ }^{7} \mathrm{Be}$, i.e., the sum of dry and wet fallout, per unit of precipitation between $30^{\circ}$ and $70^{\circ} \mathrm{N}$, have been collected in Table 3 . The average for the $30 \overline{58}$ 



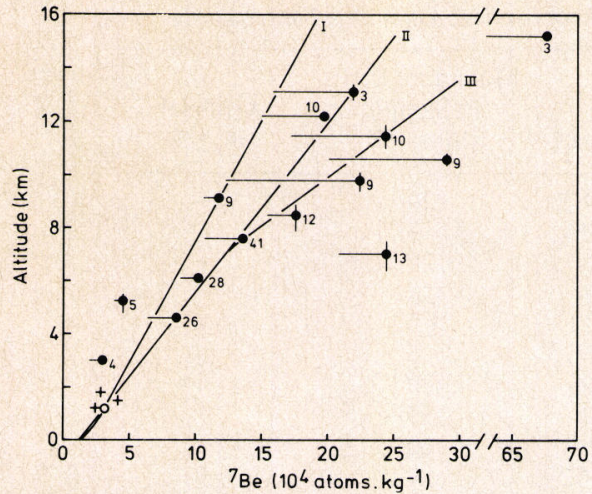

Fig. 1. Concentration of ${ }^{7} \mathrm{Be}$ in the troposphere. Data points for altitudes above $2 \mathrm{~km}$ represent averages of ${ }^{7} \mathrm{Be}$ concentrations in air sampled by aircraft. The data were taken from Feely et al. [1965, 1966], Hardy et al. [1961a, b, c, 1964, 1966a, b, 1967, 1968, 1969, 1970, 1972] (only data with a standard error of $<20 \%$ ), Rama and Honda [1961], Bhandari and Rama [1963], Young et al. [1970], Winiger et al. [1976], and Table 1 . All the data pertain to the latitude band $30^{\circ}-$ $75^{\circ} \mathrm{N}$. To reduce the chance of including results of samples taken partly in the stratosphere, data bearing on altitudes higher than $300 \mathrm{~m}$ below the tropopause have been excluded. In case no tropopause level has been reported for samples, only those taken below $8 \mathrm{~km}$ have been included. When data for different altitudes were averaged, the range of altitudes is represented by a vertical bar. A horizontal bar connects the average concentration with the average obtained after rejecting the highest value of the corresponding group of data. The numbers indicate the number of data averaged. The open circle represents the average of the data of Peirson [1963] for samples taken at $1.2 \mathrm{~km}$ about five times a week during the period October 1959 through August 1976 [Hardy, 1977]), are represented by plus signs. The value $\left(47^{\circ} \mathrm{N}, 112^{\circ} \mathrm{W} ; 1187 \mathrm{~m}\right.$, October 1973 through August 1976), Salt Lake City, Utah $\left(41^{\circ} \mathrm{N}, 111^{\circ} \mathrm{W} ; 1516 \mathrm{~m}\right.$, January 1972 through December 1974), and Rocky Flats, Colorado $\left(40^{\circ} \mathrm{N}, 105^{\circ} \mathrm{W}\right.$; average of stations I $(1830 \mathrm{~m})$ and II $(1738 \mathrm{~m})$ for period September 1972 through August 1976 [Hardy, 1977]), are represented by plus signs. The value for the concentration at sea level corresponds to the average in Figure 2.

10 stations amounts to $9 \times 10^{6}$ atoms $/ 1$. Probably the best estimate of the mean deposition rate in a latitude band is the product of this value and the average precipitation rate in that band [cf. UNSCEAR, 1964; Malakhov and Pudovkina, 1970].

The mean annual precipitation in various latitude bands has been derived from the recent estimates of Jaeger [1976]. The resulting annual ${ }^{7} \mathrm{Be}$ deposition in those bands is given in Table 4.

In connection with this treatment of the deposition data it should be noted that several investigators have observed an inverse correlation between specific radioactivity and amount of precipitation for debris from nuclear test explosions. This phenomenon did not result, however, in a higher annual deposition in areas of low rainfall [UNSCEAR, 1962]. If a similar

9elation holds for ${ }^{7} \mathrm{Be}$, the yearly deposition at the comparatively wet locations where ${ }^{7} \mathrm{Be}$ deposition was actually measured (Table 3 ) will exceed that in relatively dry regions.

- The average value of the deposition of ${ }^{7} \mathrm{Be}$ at the stations in Table 3 , which amounts to $8 \times 10^{9}$ atoms $/ \mathrm{m}^{2} \mathrm{yr}$, will therefore overestimate the mean deposition at temperate latitudes. According to the assumption of a linear relation between amount of deposition and amount of precipitation in a latitude band the annual deposition of ${ }^{7} \mathrm{Be}$ in the band $30^{\circ}-80^{\circ} \mathrm{N}$ is $6.2 \times 10^{9}$ atoms $/ \mathrm{m}^{2} \mathrm{yr}$ (Table 4). This estimate may therefore be too low by maximally $30 \%$. For the other latitude bands the maximum error is smaller (see Table 4).

Several investigations of the concentration of radionuclides in the sea suggest that fallout is higher over oceans than over continents. This problem has been discussed by Volchok [1974]. The amount of ${ }^{90} \mathrm{Sr}$ produced in nuclear tests appears to balance the amounts accountable in the environment if it is assumed that fallout per unit area over the oceans equals the average fallout measured over land. Also, the stratospheric depletion of ${ }^{90} \mathrm{Sr}$ per year was found to equal the annual amount deposited on the earth's surface. No indications were found of much more precipitation on the ocean than on the adjacent land, of an excess of dry ${ }^{90} \mathrm{Sr}$ fallout in the seas, or of an extra oceanic deposition by capture of ${ }^{90} \mathrm{Sr}$-bearing aerosol particles by sea spray. Further, it appeared that land runoff could not contribute significantly to the apparent excess ${ }^{90} \mathrm{Sr}$ in the oceans. However, if contrary to this negative evidence, deposition on the sea is indeed a factor of about 2 higher than that on land [Volchok, 1974] and if ${ }^{7} \mathrm{Be}$ shows a similar behavior [cf. Silker, 1972a, b], the average deposition of this nuclide in the various latitude bands (Table 4 ) will be higher by a

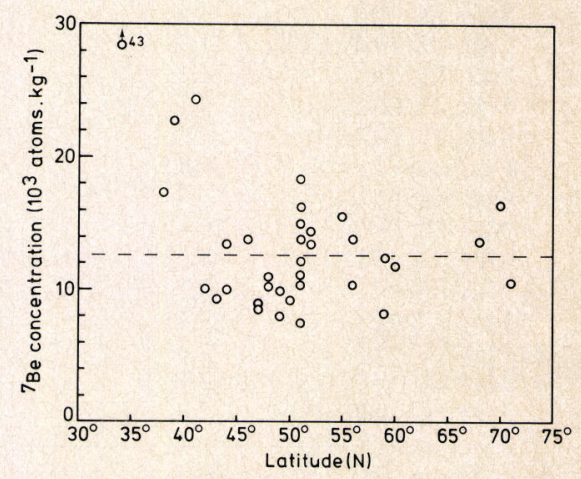

Fig. 2. Yearly average concentrations of ${ }^{7} \mathrm{Be}$ in surface air at various locations below $200-\mathrm{m}$ altitude. Data for Braunschweig $\left(52^{\circ} \mathrm{N}\right.$, $\left.10^{\circ} \mathrm{E} ; 1970-1974\right)$, Lille $\left(51^{\circ} \mathrm{N}, 3^{\circ} \mathrm{E} ; 1970-1972\right)$, Brussels $\left(51^{\circ} \mathrm{N}, 4^{\circ} \mathrm{E}\right.$; $1973-1974), \mathrm{Mol}\left(51^{\circ} \mathrm{N}, 5^{\circ} \mathrm{E} ; 1970-1974\right)$, Jülich $\left(51^{\circ} \mathrm{N}, 6^{\circ} \mathrm{E} ; 1974\right)$, Cherbourg $\left(50^{\circ} \mathrm{N}, 2^{\circ} \mathrm{W} ; 1970-1972\right)$, Strasbourg $\left(49^{\circ} \mathrm{N}, 8^{\circ} \mathrm{E} ; 1970-\right.$ $1972)$, Le Vésinet $\left(48^{\circ} \mathrm{N}, 2^{\circ} \mathrm{E} ; 1970-1972\right)$, Brest $\left(48^{\circ} \mathrm{N}, 5^{\circ} \mathrm{E} ; 1970\right.$ $1972)$, Tours $\left(47^{\circ} \mathrm{N}, 1^{\circ} \mathrm{E} ; 1970-1972\right)$, Bourges $\left(47^{\circ} \mathrm{N}, 2^{\circ} \mathrm{E} ; 1970\right.$ $1972)$, Nîmes $\left(44^{\circ} \mathrm{N}, 4^{\circ} \mathrm{E} ; 1970-1972\right)$, Nice $\left(44^{\circ} \mathrm{N}, 7^{\circ} \mathrm{E} ; 1970-1972\right)$, Biarritz $\left(43^{\circ} \mathrm{N}, 2^{\circ} \mathrm{W} ; 1970-1972\right)$ [Commission of the European Communities, $1972 a, b, 1974,1976]$; Kiruna $\left(68^{\circ} \mathrm{N}, 20^{\circ} \mathrm{E}\right.$; August 1973 through June 1975$)$, Grindsjön $\left(59^{\circ} \mathrm{N}, 18^{\circ} \mathrm{E}\right.$; August 1972 through June 1975), Ljungbyhed $\left(56^{\circ} \mathrm{N}, 14^{\circ} \mathrm{E}\right.$; July 1974 through June 1975$)$ [Arntsing et al., 1977]; Barrow $\left(71^{\circ} \mathrm{N}, 157^{\circ} \mathrm{W}\right.$; September 1975 through August 1976), Kap Tobin $\left(70^{\circ} \mathrm{N}, 22^{\circ} \mathrm{W}\right.$; October 1973 through August 1976 ), Moosoonee $\left(51^{\circ} \mathrm{N}, 81^{\circ} \mathrm{W}\right.$; September 1970 through August 1976 ), New York $\left(41^{\circ} \mathrm{N}, 74^{\circ} \mathrm{W}\right.$; September 1970 through August 1976), Sterling $\left(39^{\circ} \mathrm{N}, 77^{\circ} \mathrm{W}\right.$; May 1970 through April 1974$)$, Richmond $\left(38^{\circ} \mathrm{N}\right.$, $122^{\circ} \mathrm{W}$; September 1973 through August 1976) [Hardy, 1977]; Leningrad $\left(60^{\circ} \mathrm{N}, 30^{\circ} \mathrm{E} ; 1965-1968\right)$ [Gedeonov et al., 1971]; Stockholm $\left(59^{\circ} \mathrm{N}, 18^{\circ} \mathrm{E} ; 1960,1965-1966\right)$ [Lindblom, 1962, 1969]; Risö $\left(56^{\circ} \mathrm{N}\right.$, $12^{\circ} \mathrm{E}$; 1966-1967) [Aarkrog and Lippert, 1967, 1968]; Vilnius $\left(55^{\circ} \mathrm{N}\right.$, $25^{\circ} \mathrm{E} ; 48$ samples during April 1965 through May 1969) [Luyanas et al., 1970]; Rijswijk $\left(52^{\circ} \mathrm{N}, 4^{\circ} \mathrm{E}\right.$; November 1960 through October $1961,14.4 \times 10^{3}$ atoms $/ \mathrm{kg}$ ) (J. F. Bleichrodt, unpublished data, 1961); Braunschweig $\left(52^{\circ} \mathrm{N}, 10^{\circ} \mathrm{E}\right.$; 1964-1968) [Kolb, 1970]; Chilton $\left(51^{\circ} \mathrm{N}\right.$, $1^{\circ} \mathrm{W}$; October 1959 through August 1961, 1964-1965) [Peirson, 1963, also private communication, 1962$]$; Sutton $\left(51^{\circ} \mathrm{N}, 0^{\circ} \mathrm{W} ; 30\right.$ samples during January 1960 through August 1961) [Parker, 1962]; Heidelberg $\left(49^{\circ} \mathrm{N}, 9^{\circ} \mathrm{E}\right.$; July 1960 through June 1961$)$ [Schumann and Stoeppler, 1963]; Richland $\left(46^{\circ} \mathrm{N}, 119^{\circ} \mathrm{W} ; 15\right.$ samples during 1967) [Young et al., 1970]; A rgonne ( $\left.42^{\circ} \mathrm{N}, 88^{\circ} \mathrm{W} ; 1960\right)$ [Gustafson et al., 1961], calculated for branching ratio of ${ }^{7} \mathrm{Be}$ decay of $10.4 \%$ [Poenitz and Devolpi, 1973]; and Fullerton $\left(34^{\circ} \mathrm{N}, 118^{\circ} \mathrm{W}\right.$; September 1973 through July 1975) [Shapiro and Forbes-Resha, 1976]. The dashed line $\left(12.7 \times 10^{3}\right.$ atoms $/ \mathrm{kg}$ ) represents the average when the value of $43 \times 10^{3}$ atoms $/ \mathrm{kg}$ at $34^{\circ} \mathrm{N}$ is omitted. (Inclusion of this value will lead to a higher tropospheric residence time.) If the data points are given a weight corresponding with the number of years that air samples were measured, the weighted average amounts to $13.0 \times 10^{3}$ atoms $/ \mathrm{kg}$. 
TABLE 1. Concentration of Beryllium 7 in the Upper Troposphere Over the Netherlands

\begin{tabular}{|c|c|c|c|c|c|c|}
\hline $\begin{array}{c}\text { Date of } \\
\text { Sampling }\end{array}$ & $\begin{array}{l}\text { Altitude, } \\
\text { km }\end{array}$ & $\begin{array}{c}\text { Tropopause, } \\
\text { km }\end{array}$ & $10^{5} \mathrm{a}$ & $\begin{array}{l}{ }^{7} \mathrm{Be}, \\
\text { atoms } / \mathrm{kg}\end{array}$ & $\begin{array}{l}\text { Maximum Error } \\
\text { in Sample } \\
\text { Mass, } \%\end{array}$ & $\begin{array}{l}\text { Artificial } \\
{ }^{7} \mathrm{Be},{ }^{*} \%\end{array}$ \\
\hline Dec. 1,1960 & 10.7 & 12.8 & 0.88 & $\pm 0.12 \dagger$ & 20 & \\
\hline Jan. 25, 1961 & 8.2 & 10.4 & 2.04 & \pm 0.30 & 7 & \\
\hline April 20, 1961 & 8.5 & 10.2 & 4.2 & \pm 0.3 & 20 & \\
\hline April 27, 1961 & 8.8 & 10.2 & 4.1 & \pm 0.1 & 7 & \\
\hline May 25, 1961 & 8.2 & 10.0 & 2.32 & \pm 0.11 & 5 & \\
\hline June 9,1961 & 7.3 & 9.1 & 1.69 & \pm 0.06 & 5 & \\
\hline June 14,1961 & 9.7 & 11.0 & 1.25 & \pm 0.06 & 20 & \\
\hline June 22,1961 & 9.7 & 10.7 & 10.2 & \pm 0.2 & 20 & \\
\hline July 13,1961 & 7.3 & 10.7 & 1.43 & \pm 0.09 & 20 & \\
\hline Aug. 3, 1961 & 7.3 & 11.0 & 0.36 & \pm 0.02 & 4 & \\
\hline Aug. 24,1961 & 10.1 & 11.3 & 2.05 & \pm 0.06 & 4 & \\
\hline Sept. 1, 1961 & 9.8 & 11.7 & 0.89 & \pm 0.03 & 4 & 0 \\
\hline Sept. 5, 1961 & 8.8 & 10.7 & 1.37 & \pm 0.03 & 4 & 0 \\
\hline Sept. 7, 1961 & 6.7 & 7.9 & 0.77 & \pm 0.03 & 4 & 0 \\
\hline Sept. 11, 1961 & 9.8 & 11.3 & 1.01 & \pm 0.10 & 4 & 0.8 \\
\hline Sept. 15,1961 & 13.1 & 13.4 & 0.91 & \pm 0.07 & 4 & 1.8 \\
\hline Sept. 15, 1961 & 11.9 & 13.4 & 0.67 & \pm 0.10 & 4 & 0 \\
\hline Sept. 18,1961 & 13.4 & 13.7 & 3.5 & \pm 0.1 & 4 & 0.4 \\
\hline Sept. 19, 1961 & 11.9 & 13.4 & 1.55 & \pm 0.06 & 4 & 0.9 \\
\hline Sept. 22, 1961 & 12.8 & 14.0 & 2.24 & \pm 0.16 & 13 & 0 \\
\hline Sept. 22, 1961 & 9.1 & 14.0 & 1.19 & \pm 0.07 & 20 & 0 \\
\hline Sept. 25,1961 & 8.8 & 10.4 & 0.66 & \pm 0.04 & 20 & 3.3 \\
\hline Oct. 2,1961 & $7.9-8.5$ & 10.1 & 0.60 & \pm 0.03 & 20 & 17 \\
\hline Oct. 5,1961 & 9.4 & 10.7 & 1.01 & \pm 0.06 & 4 & 9.1 \\
\hline Nov. 16,1961 & 10.4 & 12.6 & 1.51 & \pm 0.07 & 20 & 10 \\
\hline March 2, 1962 & 8.8 & 10.0 & 2.07 & \pm 0.07 & 4 & 16 \\
\hline May 1,1962 & 8.5 & 10.5 & 1.73 & \pm 0.03 & 4 & 5.1 \\
\hline May 9,1962 & 9.1 & 10.7 & 1.08 & \pm 0.04 & 4 & 12 \\
\hline May 11,1962 & 7.6 & 9.6 & 1.38 & \pm 0.04 & 4 & 10 \\
\hline May 17,1962 & 7.9 & 9.1 & 1.29 & \pm 0.03 & 4 & 18 \\
\hline May 24,1962 & 7.0 & 8.7 & 1.48 & \pm 0.02 & 4 & 11 \\
\hline
\end{tabular}

The method of sampling and analysis has been described by Bleichrodt [1962] and Bleichrodt and van Abkoude [1963a]. Only results of samples containing less than $20 \%$ of artificial ${ }^{7} \mathrm{Be}$ (see asterisked footnote) have been included. The branching ratio of ${ }^{7} \mathrm{Be}$ decay has been assumed to be $10.4 \%$ [Poenitz and Devolpi, 1973].

*Artificial ${ }^{7} \mathrm{Be}$ in the samples taken after September 1, 1961, has been estimated according to Bleichrodt and van Abkoude [1963a].

†One standard deviation due to radioactivity counting.

factor of about 1.5 (the land area in these latitude bands ranges from 50 to $58 \%)$.

Some of the ${ }^{7} \mathrm{Be}$ deposited on the earth's surface might be brought down from the lower stratosphere by cloud systems penetrating the tropopause [E. R. Reiter, 1975]. This phenomenon leads to an overestimate of the deposition of tropospheric ${ }^{7} \mathrm{Be}$ and thus to an underestimate of the residence time.

In summary, the maximum possible error in the mean annual deposition results in an overestimation of the residence time by a factor of 2 for the latitude band $30^{\circ}-80^{\circ} \mathrm{N}$. For the other bands in Table 4 it is smaller.

\section{Mean Tropospheric Residence Time}

Table 4 shows minimum values for the mean tropospheric residence time for various latitude bands as obtained when curve $I$ in Figure 1 is used to estimate the tropospheric content of ${ }^{7} \mathrm{Be}$ (Table 2). If the average tropopause height is assumed to be $9 \mathrm{~km}$, which is certainly not too high [Oort and Rasmusson, 1971; Crutcher, 1969], a minimum for the tropospheric residence time of 22 days is obtained. Only for an average tropospheric concentration of ${ }^{7} \mathrm{Be}$ smaller than 1.5 times the average value observed at sea level (Figure 2) would the mean residence time have been smaller than the value of 7 days proposed by Martell and Moore [1974]. In the case of a maximum error in the estimated deposition of ${ }^{7} \mathrm{Be}$ (see discussion above) a minimal residence time of 12.5 days is obtained for the latitude band $30^{\circ}-80^{\circ} \mathrm{N}$. For the other four latitude bands considered (Table 4) a maximum error in the deposition, estimated as explained above, yields a mean residence time of 13 days.

The value of $6.6 \times 10^{8}$ atoms $\mathrm{m}^{-2}$ (Table 2), calculated with curve II in Figure 1 for an average tropopause height of $11 \mathrm{~km}$ [Oort and Rasmusson, 1971; Crutcher, 1969], will approximate the average tropospheric content of ${ }^{7} \mathrm{Be}$ much better. The residence time thus appears to be 33 days for the latitude band $40^{\circ}-60^{\circ} \mathrm{N}$. With curve III in Figure 1 and a tropopause level of $11 \mathrm{~km}$ the tropospheric content is $7.0 \times 10^{8}$ atoms $\mathrm{m}^{-2}$ (Table 2 ), and the tropospheric residence time for the latitude band $40^{\circ}-60^{\circ} \mathrm{N}$ is 35 days. This shows that uncertainties in the ${ }^{7} \mathrm{Be}$

TABLE 2. Calculated Tropospheric Content of ${ }^{7} \mathrm{Be}$

\begin{tabular}{cccc}
\hline $\begin{array}{c}\text { Assumed } \\
\text { Tropopause } \\
\text { Height, km }\end{array}$ & \multicolumn{3}{c}{ Tropospheric Content, ${ }^{*} \mathbf{1 0}^{8}$ atoms m $^{-2}$} \\
\cline { 2 - 4 } & Curve I & Curve II & Curve III \\
\hline 8 & 3.7 & 4.4 & 4.5 \\
9 & 4.3 & 5.2 & 5.3 \\
10 & 4.8 & 5.9 & 6.1 \\
11 & 5.4 & 6.6 & 7.0 \\
12 & 5.8 & 7.2 & 7.8 \\
\hline
\end{tabular}

*Curves in Figure 1 were used for calculations. 
TABLE 3. Deposition of ${ }^{7} \mathrm{Be}$ at Various Locations in the Northern Hemisphere

\begin{tabular}{|c|c|c|c|c|c|}
\hline Location & $\begin{array}{l}\text { Geographic } \\
\text { Coordinates }\end{array}$ & Sampling Period & $\begin{array}{l}\text { Rainfall, },^{a} \\
\mathrm{~mm} / \mathrm{yr}\end{array}$ & $\begin{array}{c}{ }^{7} \mathrm{Be} \\
\text { Concentration } \\
\text { in Rain, }{ }^{b} \\
10^{6} \text { atoms } / 1\end{array}$ & Reference \\
\hline Leningrad & $60^{\circ} \mathrm{N}, 30^{\circ} \mathrm{E}$ & $1964-1965^{c}$ & 659 & 11.2 & Gedeonov and Rys'yev [1969] \\
\hline Milford Haven & $52^{\circ} \mathrm{N}, 5^{\circ} \mathrm{W}$ & October 1959 through August $1961^{d}$ & 1374 & 8.2 & Peirson [1963] \\
\hline Rijswijk & $52^{\circ} \mathrm{N}, 4^{\circ} \mathrm{E}$ & November 1960 through August & 905 & 11.6 & Bleichrodt and van Abkoude [1963b] \\
\hline De Bilt & $52^{\circ} \mathrm{N}, 5^{\circ} \mathrm{E}$ & $\begin{array}{c}1962^{e} \\
1970-1975\end{array}$ & 723 & 6.0 & $\begin{array}{l}\text { Ministry of Health and Environment } \\
\text { [1971-1976] }\end{array}$ \\
\hline Chilton & $51^{\circ} \mathrm{N}, 1^{\circ} \mathrm{W}$ & October 1959 through August $1961^{d}$ & 838 & 7.2 & Peirson $[1963]$ \\
\hline Lille & $51^{\circ} \mathrm{N}, 3^{\circ} \mathrm{E}$ & 1970,1972 & 647 & $5.6-5.9^{f}$ & $\begin{array}{l}\text { Commission of the European Com- } \\
\text { munities }[1972 a, 1974]\end{array}$ \\
\hline Heidelberg & $49^{\circ} \mathrm{N}, 9^{\circ} \mathrm{E}$ & June 1960 through May 1961 & 780 & 9.6 & Schumann and Stoeppler [1963] \\
\hline Freiburg & $48^{\circ} \mathrm{N}, 8^{\circ} \mathrm{E}$ & $1965-1969$ & 991 & 15.5 & Hartwig and Sittkus [1972] \\
\hline Rome & $42^{\circ} \mathrm{N}, 13^{\circ} \mathrm{E}$ & $1973-1974$ & 697 & 9.6 & $\begin{array}{l}\text { Commission of the European Com- } \\
\text { munities [1976] }\end{array}$ \\
\hline Osaka & $35^{\circ} \mathrm{N}, 136^{\circ} \mathrm{E}$ & $1970-1973$ & 1196 & 5.7 & Matsunami et al. [1974] \\
\hline
\end{tabular}

${ }^{a}$ Average precipitation for sampling period.

${ }^{b}$ Ratio of total ${ }^{7} \mathrm{Be}$ deposition during sampling period of whole number of years and total precipitation.

${ }^{c}$ Dash means 1964 through 1965.

${ }^{d}$ Periods considered are October 1959 through September 1960 and September 1960 through August 1961.

e Periods considered are November 1960 through October 1961 and September 1961 through August 1962.

${ }^{\prime}$ In some monthly samples the activity of ${ }^{7} \mathrm{Be}$ was below a particular limit. The higher value is obtained by assuming the ${ }^{7} \mathrm{Be}$ concentration

in these samples to correspond to the limit value, and the lower one by taking the ${ }^{7} \mathrm{Be}$ concentration to be zero.

TABLE 4. Mean Tropospheric Residence Time of ${ }^{7} \mathrm{Be} \cdot$ for Various Latitude Bands as Calculated With Curve I in Figure 1 for Different Tropopause Levels

\begin{tabular}{cccccc}
\hline Latitude Band & $\begin{array}{c}\text { Average Annual } \\
\text { Rainfall, mm }\end{array}$ & $\begin{array}{c}\text { Average Annual } \\
\text { Deposition, } \\
\text { atoms } / \mathrm{m}^{2} \mathrm{yr}\end{array}$ & \multicolumn{3}{c}{ Residence Time, days } \\
\cline { 5 - 6 } & 800 & $7.2 \times 10^{9}$ & 22 & $10 \mathrm{~km}^{*}$ & $11 \mathrm{~km}^{*}$ \\
\hline $40^{\circ}-60^{\circ} \mathrm{N}$ & 720 & $6.5 \times 10^{9}$ & 24 & 24 & 27 \\
$40^{\circ}-70^{\circ} \mathrm{N}$ & 790 & $7.1 \times 10^{9}$ & 22 & 25 & 30 \\
$30^{\circ}-60^{\circ} \mathrm{N}$ & 730 & $6.6 \times 10^{9}$ & 24 & 27 & 30 \\
$30^{\circ}-70^{\circ} \mathrm{N}$ & 690 & $6.2 \times 10^{9}$ & 25 & 28 & 32 \\
$30^{\circ}-80^{\circ} \mathrm{N}$ & & & & & \\
\hline
\end{tabular}

*Tropopause level.

concentration in the upper troposphere do not affect the final result appreciably. For the other latitude bands mentioned in Table 4 the calculated residence times are a little longer.

A mean tropospheric residence time of the order of 35 days is in agreement with previous estimates [cf. Martell and Moore, 1974]. It may be concluded that there is no experimental evidence to support the suggestion of Martell and Moore [1974] that the residence time of cosmic-ray-produced nuclides is as small as the value of less than 1 week, which was deduced for ${ }^{222} \mathrm{Rn}$ decay products.

Acknowledgments. I am greatly indebted to the Royal Netherlands Air Force and the Royal Netherlands Meteorological Institute for taking the tropospheric samples over the Netherlands and to W. N. Lablans of the latter institute for bringing several references to my attention. Many years ago, D. H. Peirson kindly provided me with some unpublished data used in Figure 2. The constructive criticism of the reviewers of this journal with regard to the first version of this paper is gratefully acknowledged.

\section{REFERENCES}

Aarkrog, A., and J. Lippert, Environmental radioactivity in Denmark 1966, Risö Rep. 154, Dan. At. Energy Comm., Res. Estab. Risö, Risö, Denmark, 1967.

Aarkrog, A., and J. Lippert, Environmental radioactivity in Denmark 1967, Risö Rep. 180, Dan. At. Energy Comm., Res. Estab. Risö, Risö, Denmark, 1968.

Arntsing, R., L.-E. De Geer, and I. Vintersved, Radioactivity from nuclear explosions in ground level air at three Swedish sampling stations: $\mathrm{Ge}(\mathrm{Li})-\mathrm{measurements} \mathrm{up} \mathrm{to} \mathrm{mid-year} \mathrm{1975,} \mathrm{Environmental}$ Quarterly, Rep. HASL-315, edited by E. P. Hardy, pp. I-3-I-57, Health and Safety Lab., Energy Res. and Develop. Admin., New York, Jan. 1, 1977.

Bhandari, N., and Rama, Atmospheric circulation from observations of sodium 22 and other short-lived natural radioactivities, $J$. Geophys. Res., 68, 1959-1966, 1963.

Bleichrodt, J. F., Increased concentration of beryllium-7 in the stratosphere after the nuclear test explosions during September-October 1961, Nature, 193, 1065-1066, 1962.

Bleichrodt, J. F., and E. R. van Abkoude, Artificial beryllium 7 in the lower stratosphere, J. Geophys. Res., 68, 4629-4631, $1963 a$.

Bleichrodt, J. F., and E. R. van Abkoude, On the deposition of cosmic-ray-produced beryllium 7, J. Geophys. Res., 68, 5283-5288, $1963 b$.

Commission of the European Communities, Results of environmental radioactivity measurements in the member states of the European Community for 1970: Air-deposition-water, Rep. EUR 4767, Luxembourg, 1972a.

Commission of the European Communities, Results of environmental radioactivity measurements in the member states of the European Community for 1971: Air-deposition-water, Rep. EUR 4907, Luxembourg, $1972 b$.

Commission of the European Communities, Results of environmental radioactivity measurements in the member states of the European Community for 1972: Air-deposition-water, Rep. EUR 5105, Luxembourg, 1974.

Commission of the European Communities, Results of environmental radioactivity measurements in the member states of the European Community: Air-deposition-water 1973-1974, milk 1972-19731974, Rep. EUR, Luxembourg, 1976. 
Crutcher, H. L., Temperature and humidity in the troposphere, in Climate of the Free Atmosphere, vol. 4, World Survey of Climatology, edited by D. F. Rex, chap. 3, pp. 45-83, Elsevier, New York, 1969.

Feely, H. W., et al., Flight data and results of radiochemical analyses of filter samples collected during 1961 and 1962 under project Star Dust, Rep. HASL-153, Health and Safety Lab., U.S. At. Energy Comm., New York, Jan. 1, 1965.

Feely, H. W., et al., Flight data and results of radiochemical analyses of filter samples collected during 1963 under project Star Dust, Rep. HASL-168, Health and Safety Lab., U.S. At. Energy Comm., New York, March 15, 1966.

Freudenthal, $\mathrm{P} ., \mathrm{Sr}^{90}$ in surface air over the North Atlantic Ocean, Health and Safety Laboratory Report, Rep. HASL-204, edited by E. P. Hardy and J. Rivera, pp. I-98-I-108, U.S. At. Energy Comm., New York, Jan. 1, 1969.

Gedeonov, L. I., and O. A. Rys'yev, Use of cosmogenic radioisotope migration patterns in the study of the propagation of radioactive contamination in the atmosphere, I, Annual course of variations in the concentration of beryllium-7, sulfur- 35 and phosphorus-32 in surface air and in fallout in the area of Leningrad during 1963-1966, USSR Reports on Natural and Fallout Radioactivity, translated from Russian, Rep. $A-A C-82 / G / L-1306$, Transl. $A E C-t r-7128$, pp. 263-280, 1969

Gedeonov, L. I., Z. G. Gritchenko, and V. M. Flegontov, Seasonal beryllium-7 variations in ground level air, in Nuclear Meteorology, edıed by K. P. Makhon'ko and S. G. Malakhov, Gidrometeoizdat, Moscow, 1971, 1972. (Translated from Russian, pp. 208-212, Israel Program for Scientific Translations, Jerusalem, 1974.)

Gustafson, P. F., M. A. Kerrigan, and S. S. Brar, Comparison of beryllium-7 and caesium-137 radioactivity in ground-level air, $\mathrm{Na}$ ture, 191, 454-456, 1961.

Hardy, E. P. (Ed.), Fallout program quarterly summary report, Rep. HASL-227, p. III-13, Health and Safety Lab., U.S. At. Energy Comm., New York, July 1, 1970.

Hardy, E. P. (Ed.), Fallout program quarterly summary report, Rep. HASL-246, p. III-11, Health and Safety Lab., U.S. At. Energy Comm., New York, Jan. 1, 1972.

Hardy, E. P. (Ed.), Environmental quarterly, Rep. HASL-315, p. B-1, Health and Safety Lab., Energy Res. and Develop. Admin., New York, Jan. 1, 1977.

Hardy, E. P., et al. (Eds.), Fallout program quarterly summary report, Rep. HASL-105, p. 150, Health and Safety Lab., U.S. At. Energy Comm., New York, Jan. 9, 1961a.

Hardy, E. P., et al. (Eds.), Fallout program quarterly summary report, Rep. HASL-115, pp. 177, 184, Health and Safety Lab., U.S. At. Energy Comm., New York, Oct. 1, $1961 b$.

Hardy, E. P., et al. (Eds.), Fallout program quarterly summary report, Rep. HASL-117, p. 225, Health and Safety Lab., U.S. At. Energy Comm., New York, Dec. 30, 1961 c

Hardy, E. P., et al. (Eds.), Fallout program quarterly summary report, Rep. HASL-142, pp. 272, 277, Health and Safety Lab., U.S. At. Energy Comm., New York, Jan. 1, 1964.

Hardy, E. P., et al. (Eds.), Fallout program quarterly summary report, Rep. HASL-165, p. 301, Health and Safety Lab., U.S. At. Energy Comm., New York, Jan. 1, $1966 a$.

Hardy, E. P., et al. (Eds.), Fallout program quarterly summary report, Rep. HASL-172, p. I-64, Health and Safety Lab., U.S. At. Energy Comm., New York, July 1, $1966 b$.

Hardy, E. P., et al. (Eds.), Fallout program quarterly summary report, Rep. HASL-182, p. III-30, Health and Safety Lab., U.S. At. Energy Comm., New York, July 1, 1967.

Hardy, E. P., et al. (Eds.), Fallout program quarterly summary report, Rep. HASL-193, p. I-208, Health and Safety Lab., U.S. At. Energy Comm., New York, April 1, 1968.

Hardy, E. P., et al. (Eds.), Fallout program quarterly summary report, Rep. HASL-214, p. III-12, Health and Safety Lab., U.S. At. Energy Comm., New York, Oct. 1. 1969.

Hartwig, S., and A. Sittkus, Bestimmung atmosphärischer Austauschgrössen aus Konzentrationsmessungen von Spallationsprodukten, Z. Naturforsch. A, 27, 1413-1417, 1972.

Jaeger, L., Monatskarten des Niederschlags für die ganze Erde, Ber. Deut. Wetterdienstes, 139(18), 1976.

Kolb, W., Jahreszeitliche Schwankungen der ${ }^{7} \mathrm{Be}-,{ }^{54} \mathrm{Mn}$ - und Spaltprodukt-Konzentrationen der bodennahen Luft, Tellus, 22, 443-450, 1970.

Lal, D., and H. E. Suess, The radioactivity of the atmosphere and hydrosphere, Annu. Rev. Nucl. Sci., 18, 407-434, 1968.
Lindblom, G., Determination of concentration of caesium-137 in precipitation and ground-level air in Sweden, Nature, 193, 866-867, 1962.

Lindblom, G., Fallout gamma-emitting radionuclides in air, precipitation, and the human body up to spring 1967 , Tellus, 21, 127-135, 1969.

Luyanas, V. Yu., R. Yu. Yasyulyonis, D. A. Shopauskiene, and B. I. Styra, Cosmogenic ${ }^{22} \mathrm{Na},{ }^{7} \mathrm{Be},{ }^{32} \mathrm{P}$, and ${ }^{33} \mathrm{P}$ in atmospheric dynamics research, J. Geophys. Res., 75, 3665-3667, 1970.

Malakhov, S. G., and J. B. Pudovkina, Strontium 90 fallout distribution at middle latitudes of the northern and southern hemispheres and its relation to precipitation, J. Geophys. Res., 75, 3623-3628, 1970.

Martell, E. A., and H. E. Moore, Tropospheric aerosol residence times: A critical review, J. Rech. Atmos., 8, 903-910, 1974.

Matsunami, T., A. Mizohata, and T. Mamuro, Some attempts to interpret the variations with time of monthly depositions of ${ }^{210} \mathrm{~Pb}$, ${ }^{7} \mathrm{Be},{ }^{137} \mathrm{Cs}$ and ${ }^{144} \mathrm{Ce}$, Annu. Rep. Radiat. Cent. Osaka Prefect., 15 , $24-29,1974$.

Ministry of Health and Environment, General radioactive contamination of the biosphere: Measurements in the Netherlands 1970 through 1975, Versl. Adviezen Rapp. 31, 30, 12, 32, 26, 23, Staatsuitgeverij, The Hague, Netherlands, 1971-1976.

Oort, A. H., and E. M. Rasmusson, Atmospheric circulation statistics, Prof. Pap. 5, Nat. Oceanic and Atmos. Admin., U.S. Dep. of Commer., Washington, D. C., 1971

Parker, R. P., Beryllium 7 and fission products in surface air, Nature 193, 967-968, 1962.

Peirson, D. H., Beryllium 7 in air and rain, J. Geophys. Res., 68, 3831$3832,1963$.

Poenitz, W. P., and A. Devolpi, The branching ratios of ${ }^{7} \mathrm{Be}$ and ${ }^{65} \mathrm{Zn}$, Int. J. Appl. Radiat. Isotop., 24, 471-475, 1973.

Rama, and $M$. Honda, Natural radioactivity in the atmosphere, $J$. Geophys. Res., 66, 3227-3231, 1961.

Reiter, E. R., Stratospheric-tropospheric exchange processes, Rev. Geophys. Space Phys., 13, 459-474, 1975.

Reiter, R., R. Sládkovič, K. Pötzl, W. Carnuth, and H.-J. Kanter, Studies on the influx of stratospheric air into lower troposphere using cosmic-ray produced radionuclides and fallout, Arch. Meteorol. Geophys. Bioklimatol., Ser. A, 20, 211-246, 1971.

Schumann, G., and M. Stoeppler, Beryllium 7 in the atmosphere, $J$. Geophys. Res., 68, 3827-3830, 1963

Shapiro, M. H., and J. L. Forbes-Resha, Mean residence time of ${ }^{7} \mathrm{Be}-$ bearing aerosols in the troposphere, J. Geophys. Res., 81, 26472649, 1976.

Silker, W. B., Horizontal and vertical distributions of radionuclides in the North Pacific Ocean, J. Geophys. Res., 77, 1061-1070, $1972 a$.

Silker, W. B., Beryllium-7 and fission products in the Geosecs II water column and applications of their oceanic distributions, Earth Planet. Sci. Lett., 16, 131-137, 1972b.

Sissenwine, N., Standard and supplemental atmospheres, in Climate of the Free Atmosphere, vol. 4, World Survey of Climatology, edited by D. F. Rex, chap. 2, pp. 5-44, Elsevier, New York, 1969.

UNSCEAR, Report of the United Nations Scientific Committee on the Effects of Atomic Radiation, official records, 17th session, suppl. 16 (A/5216), p. 249, U.N. Gen. Assem., New York, 1962.

UNSCEAR, Report of the United Nations Scientific Committee on the Effects of Atomic Radiation, official records, 19th session, suppl. 14 (A/5814), pp. 16, 18, U.N. Gen. Assem., New York, 1964.

Volchok, H. L., Is there excess $\mathrm{Sr}^{90}$ fallout in the oceans?, Health and Safety Laboratory Report, Rep. HASL-286, edited by E. P. Hardy, pp. I-82-I-89, U.S. At. Energy Comm., New York, Oct. 1, 1974.

Walton, A., and R. E. Fried, The deposition of beryllium 7 and phosphorus 32 in precipitation at north temperate latitudes, $J$. Geophys. Res., 67, 5335-5340, 1962.

Winiger, P., O. Huber, J. Halter, and B. Michaud, Konzentrationsmessungen von Be-7, Cs-137 und jungen Spaltfragmenten an der Tropopause, Tellus, 28, 434-441, 1976.

Young, J. A., N. A. Wogman, C. W. Thomas, and R. W. Perkins, Short lived cosmic ray-produced radionuclides as tracers of atmospheric processes, in Radionuclides in the Environment, Advan. Chem. Ser., vol. 93, pp. 506-521, American Chemical Society, Washington, D. C., 1970.

(Received April 26, 1977; revised December 29, 1977; accepted January 5, 1978.) 